\title{
Dietary levels of methionine plus cystine and chelated copper on the chemical composition of eggs and yolk cholesterol of 49-week-old brown laying hens
}

\section{Níveis dietéticos de Metionina + Cistina e cobre quelatado sobre a composição química e colesterol dos ovos de poedeiras marrons com 49 semanas de idade}

\author{
Janaina Cristina da Silva Maciel de Souza ${ }^{1}$; Messias Alves Trindade Neto ${ }^{2 *}$
}

\section{Highlights:}

Interaction of dietary levels of methionine + cystine and organic copper.

Chemical composition of the egg.

Met + Cys was determinant on yolk cholesterol concentration in laying hens.

\begin{abstract}
The present study aims to evaluate the possible interactions of dietary levels of methionine plus cystine (Met + Cys) and organic copper $(\mathrm{Cu})$ on the chemical composition of eggs, using 320 Hy-Line Brown hens at 49 weeks of age. Composition and deposition variables were evaluated in a $4 \times 5$ factorial arrangement, with total analysed levels of $18,44,71$, and $99 \mathrm{mg} \mathrm{kg}^{-1}$ of $\mathrm{Cu}$ and $0.613,0.631,0.816$, 0.918 , and $0.955 \%$ Met + Cys. We allocated four replicate cages (four hens/cage) to each treatment group. Two eggs per plot were sampled to determine the chemical composition of albumen and yolk, based on natural and dry matter and on daily rates of deposition. An interaction effect of Met + Cys and $\mathrm{Cu}$ levels was observed for deposition rates of ash and $\mathrm{Cu}$ in the yolk, and the chemical composition of Ethereal Extract (EE) and ash in eggs, EE in albumen and Nitrogen, EE, and ash in the yolk. An isolated effect was observed for Met + Cys on egg chemical composition and on shell and yolk fractions, as well as on deposition rates of albumen N, EE, and ash, and yolk EE. The yolk cholesterol content increased by $18.17 \%$ with increasing Met + Cys in diets. In conclusion, the chemical composition of eggs varied with dietary Met + Cys and organic $\mathrm{Cu}$ concentrations. Dietary levels of Met + Cys determined the yolk cholesterol concentration in laying hens.
\end{abstract}

Key words: Egg quality. Nutrients deposition. Organic minerals. Sulphur amino acids.

\section{Resumo}

O presente estudo teve como objetivo avaliar as possíveis interações dos níveis alimentares de metionina mais cistina (Met + Cys) e cobre orgânico $(\mathrm{Cu})$ na composição química dos ovos, utilizando 320 galinhas Hy-Line Brown com 49 semanas de idade. As variáveis de composição e deposição foram avaliadas em arranjo fatorial $4 \times 5$, com níveis totais analisados de 18, 44, 71 e 99 mg kg-1 de Cu e 0,613, 0,631,

\footnotetext{
Discente de Doutorado, Departamento de Nutrição e Produção Animal, Faculdade de Medicina Veterinária e Zootecnia, Universidade de São Paulo, USP, Pirassununga, SP, Brasil. E-mail: janainacristina@usp.br

2 Prof. Associado, Departamento de Nutrição e Produção Animal, Faculdade de Medicina Veterinária e Zootecnia, USP, Pirassununga, SP, Brasil, E-mail: messiastn@usp.br

* Author for correspondence
} 
0,816, 0,918 e $0,955 \%$ de Met + Cys. Alocaram-se quatro gaiolas replicadas (quatro galinhas / gaiola) para cada grupo de tratamento. Foram amostrados dois ovos por parcela para determinar a composição química do albúmen e da gema, com base na matéria natural e seca e nas taxas diárias de deposição. Foi observado um efeito de interação dos níveis de Met + Cys e Cu para as taxas de deposição de cinzas e $\mathrm{Cu}$ na gema e composição química do Extrato Etéreo (EE) e cinzas nos ovos, EE no albume e nitrogênio, EE e cinzas na gema. gema. Um efeito isolado foi observado para Met + Cys na composição química dos ovos e nas frações de casca e gema, bem como nas taxas de deposição de $\mathrm{N}$ no albúmen, EE e cinzas e gema EE. O teor de colesterol na gema aumentou $18,17 \%$ com o aumento de Met + Cys nas dietas. A composição do ovo variou com as concentrações de Met + Cys e $\mathrm{Cu}$ orgânico. Os níveis alimentares de Met + Cys determinaram a concentração de colesterol na gema em galinhas poedeiras.

Palavras-chave: Qualidade do ovo. Deposição de nutrientes. Minerais orgânicos. Aminoácidos sulfurados.

\section{Introduction}

In 2018, Brazil produced about 44.5 billion eggs, $11.45 \%$ more than in 2017 . However, egg consumption is still considered low, representing only 212 per capita, as a consequence of contradictory information on the cholesterol content of eggs and possible harm that consumption causes to health (Empresa Brasileira de Pesquisa Agropecuária [EMBRAPA], 2019). Good quality eggs are, unquestionably, a source of dietary nutrients for children and adults. Albumen and yolk contain several proteins with high biological value, with the most important being ovotransferrin and ovalbumin (Leeson \& Summers, 2005).

Egg are composed of 9.5\% eggshell, 24.0\% yolk, and $67.5 \%$ albumen (Souza, 2017). On average, the cholesterol content of egg yolk varies according to weight: an egg with $60 \mathrm{~g}$ of yolk provides about $210 \mathrm{mg}$ of cholesterol (Leeson \& Summers, 2001; Spence, Jenkins, \& Davignon, 2010).

Methionine is considered an essential amino acid and cystine is semi-essential, although this classification may vary among species. Methionine has an important role in metabolism, as it participates in the metabolic pathways of compounds such as adrenaline and creatine. It is a key component in protein synthesis, which is impaired if there is methionine deficiency, and it is present in most animal tissues (Dalibard et al., 2014). hens are fed inconsistent diets, with methionine content varying from high to deficient, laying performance is affected by an excess of fat in the ovary and liver (Bertechini, 2004). Methionine also participates in lipid biosynthesis, being involved in the transport of lipids in the blood (Patterson \& Kung, 1988). DL-methionine is usually considered the first limiting amino acid for birds. When bird's diets are supplemented with amino acids, protein, nitrogen utilization and amino acid balance improve (Bunchasak \& Silapasorn, 2005).

Both methionine and proteins influence egg size (Leeson \& Summers, 2005) and methionine levels can be adjusted to control the egg size of late-cycle laying hens (Leeson \& Summers, 2005). According to Summers, Atkinson and Spratt (1991), the use of methionine in a diet containing $10 \%$ crude protein $(\mathrm{CP})$ produced a $10 \%$ increase in egg mass. However, Penz and Jensen (1990) found low egg and albumen weight for birds that received diets with only $13 \%$ CP. Increased egg production was observed by Solarte, Rostagno, Soares, Silva and Velasquez (2005) when laying hens received $0.684 \%$ methionine plus cystine (Met + Cys). According to Gambaro (2014), birds fed $0.77 \%$ Met + Cys had higher egg weights, compared to birds fed diets with only $0.66 \%$ Met + Cys. Barbosa et al. (1999) observed the same change in egg weight when Met + Cys were included in the diet of white and brown egg-laying hens. According to Brumano et al. (2010), increased Met + Cys consumption by light laying hens at 20 to 40 weeks resulted in increased 
yolk percentage. Polese (2011) also found increasing Met + Cys levels increased the percentage of yolk, and the author argues that this was a consequence of choline synthesis, followed by the formation of yolk lipoproteins. Microminerals, which are also important for egg-laying, can be chelated or inorganic; chelates bind metal ions to other organic substances, making them more bioavailable than inorganic forms of minerals (Saldanha, 2008). For many years inorganic minerals have been used as low-cost dietary supplements, but recent studies (Nunes et al., 2013; Alves, Bastos-Leite, Goulart; Silva, \& Medeiros 2015; Carvalho, Vilela, Fagundes, Souza, \& Fernandes, 2016) suggest that use of organic minerals is more effective, because they are more bioavailable and are excreted less, reducing environmental pollution. Organic minerals $(\mathrm{Cu}$ and $\mathrm{Zn})$ are involved in eggshell membrane formation (Baumgartner, Brown, Salevsky, Jr., \& Leach, Jr., 1978), participate in enzymatic activities, and are important for animal health (Mabe, Rapp, Bain, \& Nys, 2003; Richards, Zhao, Harrell, Atwell, \& Dibner, 2010; Scottá et al., 2014; Rezende, 2016).

Mabe et al. (2003) reported that supplementing laying hen diets with organic $\mathrm{Cu}$ and $\mathrm{Zn}$ altered the mechanism of shell formation, probably by their interaction with calcium carbonate, modifying the texture of the shell. The addition of organic rather than inorganic minerals can increase egg weight and improve shell quality and bone strength of semiheavy laying hens (Nunes et al., 2013). Carvalho et al. (2016) found it was possible to replace up to $70 \%$ of microminerals from inorganic sources with organic ones, improving shell quality, without affecting the birds' performance.

In 1883, Boutigny demonstrated the presence of copper in animal tissues. However, it was only in 1920 that studies in rats demonstrated that iron and copper were necessary for haemoglobin formation. Although not part of haemoglobin, copper is present in plasma proteins involved in the release of iron into plasma (Lesson \& Summers, 2001). It is an important trace mineral for birds, being necessary in bone formation and as a component of extra and intracellular enzymes, such as cytochrome oxidase. Copper deficiency results in a difficulty in iron absorption and its mobilization from tissues (Lesson \& Summers, 2001; Olgun, Yazgan, \& Cufadar, 2013). Copper is absorbed by excess $\mathrm{Ca}, \mathrm{Fe}$, and $\mathrm{Zn}$ in the diet, and, in poultry, its deficiency produces anaemia, reproductive failure, and bone fragility (Scottá et al., 2014) and reduces lipoprotein lipase activity in extra-celular parts of tissues and liver cells (Valsala \& Kurup, 1987).

According to Baumgartner et al. (1978), Cu deficiency in the diet affects eggshell quality. However, they found there was an increase in egg weight, which they contributed to changes in egg membranes and to the increase in albumen weight. The use of chelated $\mathrm{Cu}, \mathrm{Zn}$, and $\mathrm{Mn}$ microminerals associated with methionine resulted in improved bioavailability, compared to other sulphates added to the laying hen diet (Sun, Guo, Li, Zhang, \& Wen 2012). Dobrzánski et al. (2008) found that including chelated copper in the laying diet resulted in an increase in $\mathrm{Cu}$ in the eggshell, blood and feathers, compared to birds that received inorganic copper.

Egg quality can be improved by supplying the birds with microminerals (Sechinato, 2003), and the chelated forms may increase egg weight, as well as having good mineral bioavailability (Carvalho, 2012; Lim \& Paik, 2006). In addition to being essential to lipid metabolism, copper can affect both shell formation and quality (Baumgartner et al., 1978). According to Pesti and Bakalli (1998) and Idowu, Kuye, Oladele-Ojo and Eruvbetine (2005), dietary supplementation of copper could decrease egg cholesterol. As an essential and limiting amino acid for laying hens, methionine has a significant effect on egg weight (Kakhki, Golian, \& Zarghi, 2016; Leeson \& Summers, 2005). Sulphur amino acids, such as methionine and cystine, can modify the composition of the egg (Barbosa et al., 1999; Brumano et al., 2010; Polese, 2011). 
However, most studies using amino acids and chelated minerals have focused on isolated effects on birds and eggs, thus information on the combined effects of nutrients is still scarce. However, amino acid supplementation has been increasingly used in the poultry diets to reduce the pollution caused by the residues generated and the cost of feed production (Jenn-Chung, Chung-Yi, \& Peter WenShyg, 1998). Therefore, the present study evaluated the possible interaction of dietary levels of Met + $\mathrm{Cys}$ and chelated $\mathrm{Cu}$ on the chemical composition of eggs.

\section{Material and Methods}

The research was carried out in Pirassununga, São Paulo, Brazil (Latitude $21^{\circ} 57^{\prime} \mathrm{S}$, Longitude $47^{\circ}$ $\left.27^{\prime} \mathrm{W}\right)$. All experimental procedures were approved by the Ethics Committee on Animal Use (1589/2009 CEUA). The laboratory procedures were performed at the Laboratory of Bromatology and Monogastric Nutrition.

\section{Animals}

A total of 320 laying hens (Hy-Line Brown) were used, at 48 weeks old (around 89\% egg production), and the results of the treatments were assessed after 48 to 49 weeks. Laying hens and treatments were allocated, in a completely randomized way, to four replicate cages ( 4 hens/cage) with dimensions of 1.0 x $0.4 \times 0.4 \mathrm{~m}$ with four divisions of $0.25 \times 0.4 \times 0.4$ and two birds per division.

The birds were distributed in galvanized wire cages arranged in a line and equipped with a galvanized plate feeder and nipple drinking supply. Food and water were provided ad libitum. The artificial lighting was kept constant during the evaluation periods to ensure 17 hours of light every 24 hours.

\section{Diets and analysis}

Dietary treatments (Table 1) were assigned in a 4 x 5 factorial arrangement, using analysed levels of chelated $\mathrm{Cu}\left(18,44,71\right.$, and $\left.99 \mathrm{mg} \mathrm{kg}^{-1}\right)$ and five levels of Met + Cys (0.613, 0.631, 0.816, 0.918 , and $0.955 \%$ ). The diets were based on corn and soybean meal and formulated to meet the minimum recommendations proposed by Rostagno et al. (2011), except for Met + Cys levels. The lowest level Met + Cys diet was divided into five equal batches. DL-methionine (RHODIMET ${ }^{\circledR}$, DLmethionine $99 \%$ ) was added to the diet to obtain increased levels of this amino acid.

We formulated diets with $0,22,43$, and 88 $\mathrm{mg} \mathrm{kg}{ }^{-1}$ of supplied chelated copper. Differences between the formulated and analysed values resulted from mineral fractions in other dietary ingredients, such as corn and soybean meal. Therefore, $\mathrm{Cu}$ estimation was corrected for $18 \mathrm{mg}$ $\mathrm{kg}^{-1}$, corresponding to a concentration of $0 \mathrm{mg} \mathrm{kg}^{-1}$ (without supplementation). For estimated digestible Met + Cys, a level of $89.23 \%$ was used as an index, according to the digestible coefficient (National Research Council [NRC], 1994). This index accounted for the weighted average relationship between digestibility and the total Met + Cys from corn and soybean meal.

We sampled two eggs per plot to determine the chemical composition, including Crude protein (CP $\%)$, Ethereal Extract (EE \%), Ash (\%), Water $\left(\mathrm{H}_{2} \mathrm{O}\right.$ $\%$ ), and cholesterol, of the eggs. The egg yolk and albumen were placed in separate containers, frozen at $-40^{\circ} \mathrm{C}$, freeze-dried and ground to powder for further analysis.

Crude protein, EE and MM were analysed according to the Association of Official Analytical Chemists (AOAC, 2005), copper levels were determined using inductively coupled plasma optical emission spectrometry (Model 710 ICPOES, Agilent Technologies, Santa Clara, California, US). 
Table 1.

Ingredients and nutritional composition of experimental diets

\begin{tabular}{|c|c|c|c|c|c|}
\hline & \multicolumn{5}{|c|}{ Met + Cys Total $(\%)^{1}$} \\
\hline & 0.613 & 0.631 & 0.816 & 0.912 & 0.955 \\
\hline & \multicolumn{5}{|c|}{ Met + Cys Digestible ${ }^{2}$} \\
\hline Ingredients (\%) & 0.491 & 0.606 & 0.708 & 0.781 & 0.846 \\
\hline Corn grain & 61.028 & 61.094 & 61.231 & 61.105 & 60.767 \\
\hline Soybean meal & 23.299 & 23.063 & 22.813 & 22.827 & 23.024 \\
\hline Soybean oil & 1.893 & 1.895 & 1.839 & 1.800 & 1.800 \\
\hline L-Lysine $\mathrm{HCl}$ & 0.109 & 0.117 & 0.125 & 0.125 & 0.119 \\
\hline DL Methionine & 0.060 & 0.214 & 0.368 & 0.519 & 0.669 \\
\hline L-Threonine & 0.030 & 0.034 & 0.037 & 0.037 & 0.035 \\
\hline L-Tryptophan & 0.003 & 0.004 & 0.005 & 0.005 & 0.004 \\
\hline Salt & 0.221 & 0.221 & 0.221 & 0.221 & 0.221 \\
\hline Limestone & 11.314 & 11.314 & 11.314 & 11.314 & 11.314 \\
\hline Dicalcium phosphate & 1.471 & 1.474 & 1.476 & 1.476 & 1.475 \\
\hline Choline chloride & 0.030 & 0.030 & 0.030 & 0.030 & 0.030 \\
\hline Baking soda & 0.279 & 0.279 & 0.279 & 0.279 & 0.279 \\
\hline Kaolin or Carboquelate $\mathrm{Cu}-16 \%{ }^{5}$ & 0.063 & 0.063 & 0.063 & 0.063 & 0.063 \\
\hline Premix Vit ${ }^{3}$ & 0.100 & 0.100 & 0.100 & 0.100 & 0.100 \\
\hline Premix $\operatorname{Min}^{3}$ & 0.100 & 0.100 & 0.100 & 0.100 & 0.100 \\
\hline Total & 100.00 & 100.00 & 100.00 & 100.00 & 100.00 \\
\hline \multicolumn{6}{|l|}{ Analyzed values - $\%{ }^{4}$} \\
\hline Dry Matter & 89.30 & 89.88 & 89.47 & 89.80 & 89.22 \\
\hline Crude protein & 16.52 & 16.19 & 16.54 & 16.47 & 15.63 \\
\hline Met + Cys & 0.613 & 0.631 & 0.816 & 0.918 & 0.955 \\
\hline Methionine $^{3}$ & 0.313 & 0.373 & 0.536 & 0.635 & 0.702 \\
\hline Cystine & 0.299 & 0.258 & 0.280 & 0.282 & 0.253 \\
\hline Lysine & 0.914 & 0.840 & 0.887 & 0.917 & 0.870 \\
\hline Threonine & 0.722 & 0.626 & 0.680 & 0.737 & 0.622 \\
\hline Arginine & 0.964 & 0.788 & 0.835 & 0.878 & 0.861 \\
\hline Isoleucine & 0.682 & 0.608 & 0.652 & 0.692 & 0.589 \\
\hline Leucine & 1.545 & 1.411 & 1.479 & 1.561 & 1.337 \\
\hline Valine & 0.762 & 0.681 & 0.760 & 0.798 & 0.699 \\
\hline Alanine & 0.916 & 0.809 & 0.861 & 0.922 & 0.812 \\
\hline Histidine & 0.437 & 0.377 & 0.384 & 0.417 & 0.408 \\
\hline Phenylalanine & 0.876 & 0.802 & 0.833 & 0.910 & 0.780 \\
\hline Áspartic acid & 1.621 & 1.425 & 1.524 & 1.639 & 1.387 \\
\hline Glutamic acid & 3.082 & 2.778 & 2.925 & 3.099 & 2.706 \\
\hline Glicine & 0.634 & 0.615 & 0.626 & 0.669 & 0.573 \\
\hline Serine & 0.851 & 0.751 & 0.798 & 0.864 & 0.739 \\
\hline Tyrosine & 0.650 & 0.606 & 0.619 & 0.652 & 0.559 \\
\hline
\end{tabular}


continuation

\begin{tabular}{lccccc}
\hline${\text { Calculated values }-\%^{1}}^{1}$ & & & & & \\
Metabolizable Energy - kcal/kg & 2763 & 2768 & 2770 & 2770 & 2.770 \\
Calcium & 4.7 & 4.7 & 4.7 & 4.70 & 4.7 \\
Phosphor avaliable & 0.36 & 0.36 & 0.36 & 0.36 & 0.36 \\
Sodium & 0.18 & 0.18 & 0.18 & 0.18 & 0.18 \\
Chlorine & 0.18 & 0.18 & 0.18 & 0.18 & 0.18 \\
Linoleic acid & 2.368 & 2.368 & 2.368 & 2.317 & 2.312 \\
Digestible tryptophan & 0.168 & 0.168 & 0.168 & 0.168 & 0.168 \\
Digestible Methionine + Cystine & 0.500 & 0.650 & 0.800 & 0.950 & 1.100 \\
Digestible Lysine & 0.800 & 0.800 & 0.800 & 0.800 & 0.800 \\
Digestible Threonine & 0.560 & 0.560 & 0.560 & 0.560 & 0.560 \\
\hline
\end{tabular}

${ }^{1}$ (Natural matter) Reviewed by Ajinomoto Biolatin Industry \& Com. Ltda. ${ }^{2}$ Estimated based on laboratory analysis and the weighted average ratio of $89.23 \%$ of digestibility, used in relation to the total Methionine + Cystine of the main ingredients, according to NRC (1994). ${ }^{3}$ Provided per kg of diet: folate, $145 \mathrm{mg}$; pantothenate, $5.930 \mathrm{mg}$; niacin, $12 \mathrm{~g}$; Vit.A 5,000,000 IU; B12 6,500 mcg; B2 2,000 mg; B6 300 mg; D3 1,850,000 IU; Vit.E. 4,500 IU; Vit.K 918 mg. If (selenate) 500 mg; Fe 55g, I 1,550mg; Mn 70 g; Zn (min.) 50 g. ${ }^{4}$ Provided per kg premix: Manganese, 88 g; iron, 55g; Zinc, 88g; iodine, $1.7 \mathrm{~g}$; Selenium, $3 \mathrm{~g} .{ }^{5}$ Analyzed by CBO Brazil - 100\% chelated copper: N, 3.07\%; Ala, 0.06\%; Arg, 0.04\%; Aspartic acid, 0.02\%; Gly, 0.10\%; Ile, 0.02\%; Leu, 0.05\%; Glutamic acid, 0.12\%; Lys, 0.00; Cys, 0.03\%; Met, 0.01\%; Phe, 0.03\%; Tyr, 0.09\%; Thr, 0.06\%; Pro, 0.44\%; Val, 0.05\%; His, 0.00\%; Ser, $0.04 \%$; sum amino acids, 1.1 .

Cholesterol determination was performed using the direct saponification technique, according to the methodology described by Mazalli, Saldanha and Bragagnolo (2003). We weighed $0.25 \mathrm{~g}$ of yolk sample in $70 \mathrm{~m} \mathrm{~L}$ test tubes with screw cap, then $10 \mathrm{~m} \mathrm{~L}$ of $2 \%$ potassium hydroxide solution $(\mathrm{KOH})$ in ethyl alcohol PA (absolute alcohol) was added. The tubes containing the samples and solution were placed in a $50^{\circ} \mathrm{C}$ water bath with stirring for 2 hours. Subsequently, $5 \mathrm{~m} \mathrm{~L}$ of distilled water was added and we allowed the tubes to cool. Each tube received $10 \mathrm{~m} \mathrm{~L}$ of hexane, was then vortexed (tube shaker) for 1 minute to extract the hexanic phase (unsaponifiable matter), then this phase was transferred to other test tubes with screw caps. The hexanic phase extraction process was repeated twice for each tube. We determined cholesterol levels using a high-performance liquid chromatography (HPLC) method adapted from Mazalli et al. (2003). A solution (mobile phase) of acetonitrile and isopropanol in the ratio of $85: 15$ was prepared. Subsequently, in properly identified $1.5 \mathrm{~mL}$ vials (Vials, Agilent Technologies), $0.5 \mathrm{~mL}$ of the hexane phase was added and inserted into the lyophilizer for drying for 20 minutes. All the liquid in each vial was transferred to $5 \mathrm{~m} \mathrm{~L}$ syringes (with pore membrane), then transferred to other vials and subsequently analysed by HPLC.

\section{Statistical analysis}

The data were analysed using the SISVAR procedure 5.6. Significance was $\mathrm{P}<0.05$. The variables were submitted to regression analysis by orthogonal polynomials.

\section{Results and Discussions}

We analysed the interactions of Met + Cys and $\mathrm{Cu}$ with following variables: yolk ash deposition and yolk $\mathrm{Cu}$ (Table 2); egg EE and ash on natural matter; and yolk N, EE, ash, and $\mathrm{Cu}$ concentrations (Table 3).

We did not find relationships between the levels of Met $+\mathrm{Cys}$ and chelated-Cu and the egg weight and egg content, as shown by the statistical 
results. However, an increase in Met + Cys levels increased yolk weight. The response obtained for the variable 'egg weight' in the present study differs from Barbosa et al. (1999), who found an increase in Met + Cys levels $(0.434$ to $0.734 \%)$ resulted in an increased egg weight for light laying hens and semi-heavy laying hens. In contrast, Bendezu et al. (2015) observed that the increase in Met + Cys content coincided with a lower egg weight for laying hens in the first production cycle. Although different studies provide contrasting results, the level of methionine in laying diets is related to egg weight (Bunchasak \& Silapasorn, 2005; Brumano, 2009; Gambaro, 2014).
The effects of dietary Met + Cys and $\mathrm{Cu}$ on egg characteristics and contents and on deposition rates are presented in Table 2. Dietary increase in amino acids produced a linear increase in yolk weight $(\mathrm{P}=0.006)$. The same tendency $(\mathrm{P}<0.10)$ was observed for albumen and shell weights, according to equations presented in Table 2. Effects of Met + Cys also were observed on albumen N, EE, and Ash deposition, resulting in a positive quadratic response $(\mathrm{P}<0.01)$. The mean estimated by equations of total Met + Cys was $0.769 \pm 0.002 \%$ and digestible Met + Cys was $0.666 \pm 0.002$, based on the index from the digestible coefficients (NRC, 1994). In yolk, there was higher EE deposition at an estimated level of $0.839 \%$ of total Met + Cys or $0.749 \%$ digestible Met + Cys. 


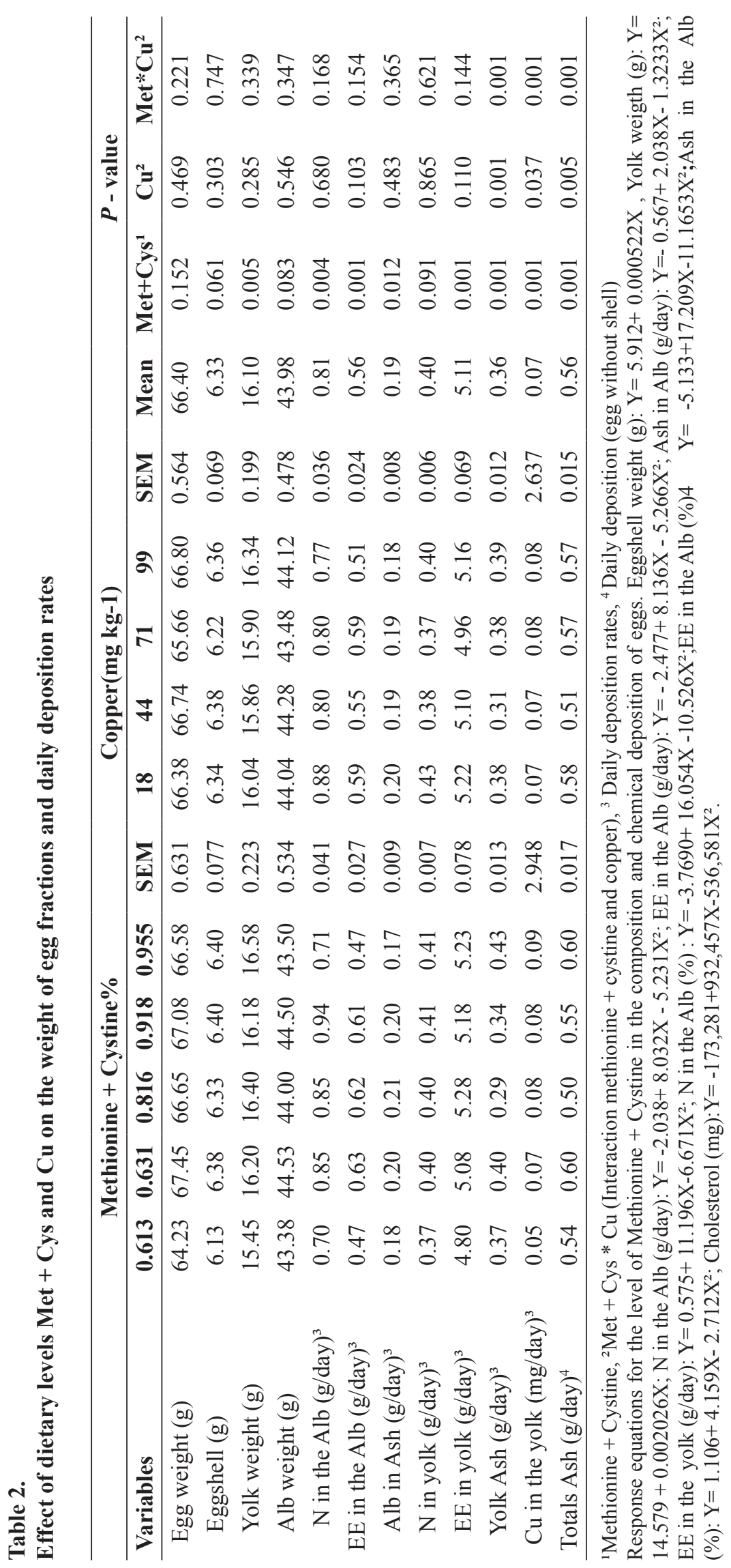




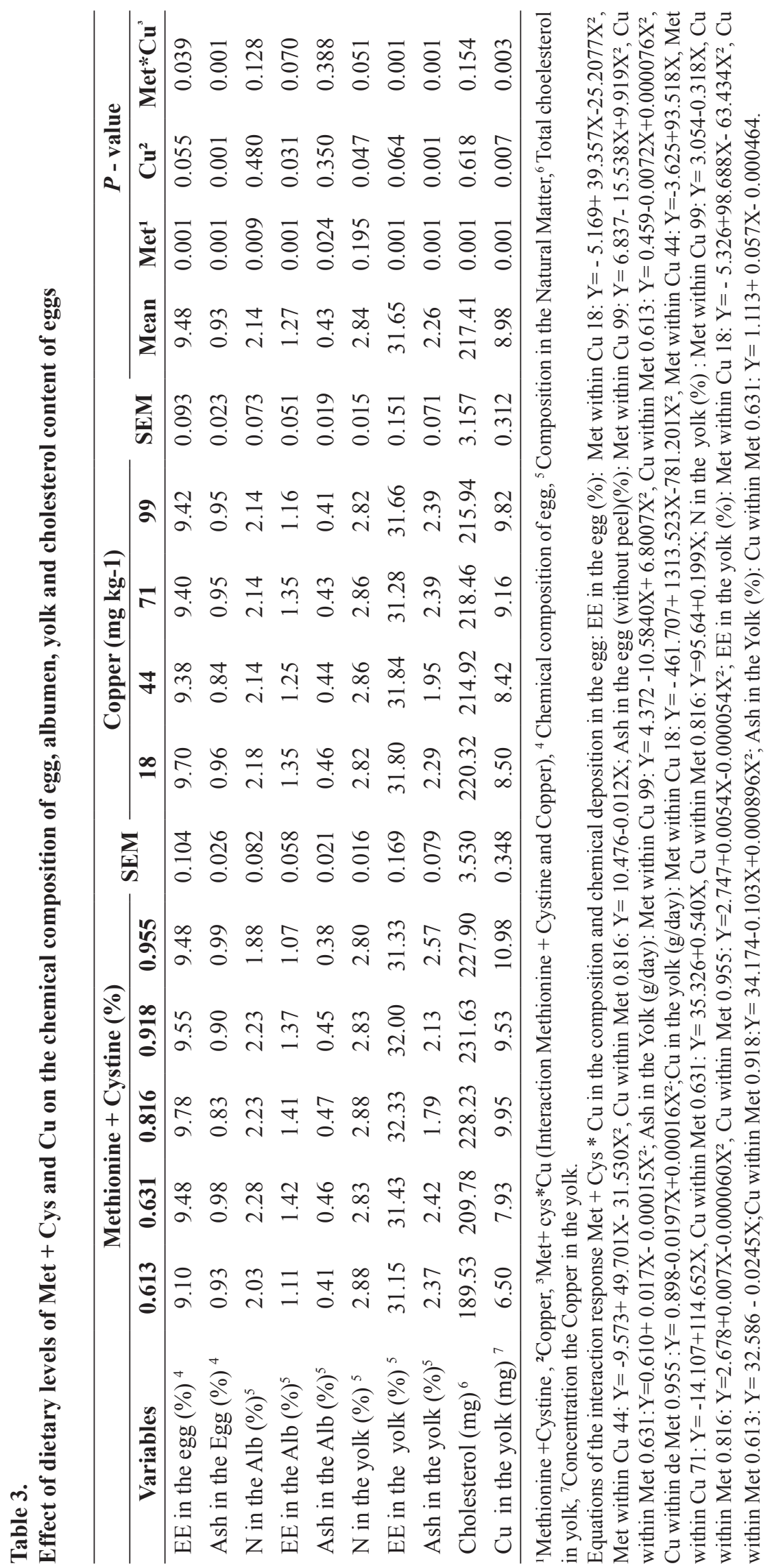

Semina: Ciências Agrárias, Londrina, v. 41, n. 1, p. 269-282, jan./fev. 2020 
Regarding the chemical deposition rates, the average increase with Met + Cys was $0.759 \pm$ $0.013 \%$, which showed a positive effect on the deposition rates of $\mathrm{N}, \mathrm{EE}$, and ash in albumin, similar to the results observed for EE deposition in the yolk. The deposition rates observed in the EE yolk and $\mathrm{N}$ albumen variables increased by 10 to $26 \%$ in response to the increase in total Met + Cys levels from 0.613 to $0.918 \%$.

We found that amounts of amino acids and trace mineral effected yolk ash and copper deposition $(\mathrm{P}<0.001)$. The increase in Met + Cys levels in the $99 \mathrm{mg} \mathrm{kg}^{-1} \mathrm{Cu}$ diet estimated $0.778 \%$ of total Met + Cys. In hens fed the diet with $18 \mathrm{mg} \mathrm{kg}^{-1} \mathrm{Cu}$, increasing of total Met + Cys concentrations up to $0.841 \%$ increased $\mathrm{Cu}$ deposition. In contrast, the variation of $\mathrm{Cu}$ in the diets with 0.631 and $0.816 \%$ of Met + Cys coincided with a linear increase $(\mathrm{P}<$ 0.05) in the deposition of $\mathrm{Cu}$ in the yolk. Whereas the varying $\mathrm{Cu}$ levels in the diets with 0.613 and $0.955 \%$ of Met + Cys resulted in an estimated (P $<0.001)$ minimum and maximum deposition of 50 and $65 \mathrm{mg} \mathrm{kg}^{-1} \mathrm{Cu}$, respectively, in the yolk.

The percentages of chemicals in the egg, albumen, yolk and cholesterol, according to the levels of Met $+\mathrm{Cys}$ and $\mathrm{Cu}$ are presented in (Table 3). Overall, the increase in amino acids within $\mathrm{Cu}$ concentrations was estimated $0.784 \pm 0.004 \%$ of total Met + Cys. However, the $\mathrm{Cu}$ concentration changes within the Met + Cys diets were found for $60.24 \pm 10.51 \mathrm{mg} \mathrm{kg}^{-1}$ or $42.24 \pm 10.51 \mathrm{mg} \mathrm{kg}^{-1}$ of supplied chelated inorganic copper.

We found that an increase in Met + Cys concentrations in diets with higher $\mathrm{Cu}$ levels produced a linear decrease $(\mathrm{P}=0.003)$ in $\mathrm{N}$ concentrations in the yolk. In the diet with $0.816 \%$ of Met $+\mathrm{Cys}, \mathrm{Cu}$ increased by $60 \mathrm{mg} \mathrm{kg}^{1}$, as estimated by the quadratic equation. The EE composition of yolk negatively correlated with varying Met + Cys levels in the diet containing $18 \mathrm{mg} \mathrm{kg}^{-1}$ of $\mathrm{Cu}$, and the EE was estimated to be optimum for $0.778 \%$ of the total amino acid. In the diet with $0.918 \%$ Met +
Cys, $58 \mathrm{mg} \mathrm{kg}^{-1}$ of $\mathrm{Cu}$ led to the lowest EE content in the yolk.

With regards to the chemical composition of the egg and its fractions, we observed that increasing Met + Cys, in diets containing 18 and $44 \mathrm{mg} \mathrm{kg}^{-1}$ $\mathrm{Cu}$, to a mean level of $0.785 \%$ increased the EE as estimated by quadratic equations. The same interaction showed the opposite effect when we increased $\mathrm{Cu}$ in the diet containing of $0.816 \%$ of total Met + Cys, as there was a linear reduction in the EE content of eggs. As regards the egg (without shell), we observed that increasing Met + Cys levels in the diet with $99 \mathrm{mg} \mathrm{kg}^{-1} \mathrm{Cu}$ resulted in a reduction of egg ash content. As reported by Medici et al. (2013), $\mathrm{Cu}$ may regulate the metabolism of methionine, which is an essential amino acid linked to polyunsaturated fatty acids (PUFA) metabolism (Maroufyan et al., 2013). Therefore, Cu may also affect the lipid composition of eggs.

The composition of $\mathrm{N}$ in the yolk was affected by the interaction between amino acids and mineral, suggesting a probable antagonistic effect. An increase in $\mathrm{Cu}$ concentrations in the diets containing 0.816 and $0.955 \%$ of Met + Cys indicated a reduction in $\mathrm{Cu}$ requirement. Therefore, when Met + Cys levels increased in the diet, the demand for $\mathrm{Cu}$ was reduced. Comparing the results of the present study with the recommendations of Rostagno et al. (2017) for productive laying hens, we found a lower average level for Met + Cys and a similar inorganic $\mathrm{Cu}$ level. The results suggest, therefore, that there was a dependant relationship in the increase in the mineral in the diets with Met + Cys, coinciding with lower need for both, according to the changes in the chemical compositions of the eggs.

The chemical composition of the eggs, expressed in Natural Matter, also presented a positive quadratic variation in response to sulphur amino acids.

The concentrations of $\mathrm{N}, \mathrm{E}$, and ash in the Albumen increased when the concentration of Met + Cys were increased in the diet, to the mean level 
of $0.767 \%$ total Met + Cys. Dietary levels of sulphur amino acids above the estimated would have a negative effect on these variables, as observed from the experimental treatment containing $0.816 \%$ of total Met + Cys .

Sulphur amino acids were observed $(\mathrm{P}=0.001)$ to affect the cholesterol content, as an increase of 0.613 to $0.918 \%$ Met + Cys resulted in an increase in the cholesterol content, as presented in Table 3. The extent to which the levels of Met + Cys increased the quadratic response was observed $(\mathrm{P}<0.001)$

The effect of Met + Cys on the increase of yolk cholesterol was about $18 \%$, suggesting that the sulphur amino acids were favourable for lipid synthesis. The increasing levels of digestible Met + Cys resulted in a higher percentage of yolk, because choline, which is synthesised from methionine, is used to make yolk lipoproteins and phospholipids (Polese, 2011). The effects of Met + Cys on the yolk cholesterol found in the present study differ from those found by Kakhki et al. (2016), who did not report an effect of these amino acids on the yolk.

The highest level of organic copper used in this study (99 $\left.\mathrm{mg} \mathrm{kg}^{-1}\right)$ did not produce significant effects, so the effects of the interaction were characterized as a regression deviation. This differs from the results found by Idowu et al. (2005) and Lien, Chen, Wu and Lu (2004), which suggested $\mathrm{Cu}$ reduced yolk cholesterol when the mineral concentration was raised to $250 \mathrm{mg} \mathrm{kg}^{-1}$. Balevi and Coskun (2004), when analysing the effect of copper, including $150 \mathrm{mg} \mathrm{kg}^{-1}$ of $\mathrm{Cu}$, on production and cholesterol, observed a reduction in yolk cholesterol without affecting the performance of the birds. However, this effect was not observed by Lim and Paik (2006), as they concluded that $\mathrm{Cu}$ had no effect on egg yolk cholesterol.

We observed a linear increase in the concentration of $\mathrm{Cu}$ in the yolk $(\mathrm{P}<0.01)$ with increasing Met + Cys content in the diets with 18, 44, and $71 \mathrm{mg}$ $\mathrm{kg}^{-1}$ copper. A similar linear increase $(\mathrm{P}<0.05)$ of $\mathrm{Cu}$ in yolk was observed with increasing $\mathrm{Cu}$ supplementation in the diets with 0.631 and $0.816 \%$ Met + Cys.

The amount of $\mathrm{Cu}$ in the yolk was dependant on the levels of Met + Cys in the diet. The same effect was observed when the concentration of copper was changed in the diets with 0.631 and $0.816 \%$ Met + Cys. The results of the present study agree with those reported by Pesti and Bakalli (1998): they observed that increasing $\mathrm{Cu}$ in the diet increased its concentration in the yolk. These observations suggest that a variation of $\mathrm{Cu}$ and $\mathrm{Met}+\mathrm{Cys}$ intake may affect the metabolism of hens. Using a rat model, Medici et al. (2013) demonstrated the interactions between $\mathrm{Cu}$ and methionine through the accumulation of $\mathrm{Cu}$, reflecting metabolism. As reported by Medici et al. (2013), Cu may regulate the metabolism of methionine, an essential amino acid linked to polyunsaturated fatty acids (PUFA) metabolism (Maroufyan et al., 2013).

As reviewed by Trindade Neto et al. (not published), methionine and $\mathrm{Cu}$ are related to metabolism through their known inhibitory effect on S-adenosylhomocysteine hydrolase, which inhibits transmethylation reactions. In this same review, the authors reported that $\mathrm{Cu}$ can also coordinate a range of ligands, including cysteine thiolate and methionine thioether groups, and engage in cation interactions. In addition, a number of copperdependent proteins and their functions have yet to be identified. Thus, many questions in the field of copper metabolism have yet to be answered.

The effects of copper on human nutrition are correlated to the immune system and the actions of antioxidants, as well as to the prevention of degenerative diseases. According to Lien et al. (2004), high levels of copper in the diet of laying hens increased the retention of $\mathrm{Cu}$ in the egg, but consuming eggs with high concentrations of $\mathrm{Cu}$ would cause health problems. In a review, Sahoo, Kataria and Mehta (2016) observed that the maximum daily intake of $\mathrm{Cu}$ should not be above 10 
$\mathrm{mg} /$ day for humans because, although $\mathrm{Cu}$ helps in reducing LDL and cellular oxidation, high amounts could affect the use of $\mathrm{Zn}$ by the body. In the present study, the average $\mathrm{Cu}$ in the yolk was $8.98 \mathrm{mg} \mathrm{kg}-$ 1, within the limit suggested by Sahoo, Kataria and Mehta (2016).

\section{Conclusion}

The chemical composition of the eggs varied with the dietary concentrations of Met + Cys and organic $\mathrm{Cu}$. The Met $+\mathrm{Cys}$ content of the laying hen diet interfered with the amount of yolk cholesterol.

\section{Acknowledgment}

This study was financed in part by the Coordination of Improvement of Higher Level Personnel - Brazil (CAPES) - Finance Code 001.

\section{References}

Alves, M. G. M.; Bastos-Leite, S. C.; Goulart, C. C.; Silva, J. D. B.; Medeiros, F. M. (2015). Substituição dos minerais inorgânicos por orgânicos e duas granulometrias de calcário na dieta de poedeiras comerciais leves. Agropecuária Técnica, 36(1), 128 -135. doi: 10.25066/agrotec.v36i1.23101

Association of Official Analytical Chemists. (2005). Official methods of analysis of the association of analytical chemists. 18nd ed. Geithersburg: AOAC.

Balevi, T., \& Coskun, B. (2004). Effects of dietary copper on production and egg cholesterol content in laying hens. British Poultry Science, 45(4), 530-534. doi: 10.1080/00071660412331286253

Barbosa, B. A. C., Soares, P. R., Rostagno, H. S., Silva, M. A., Albino, L. F. T., \& Graças, A. S. (1999). Exigência nutricional de metionina+cistina para galinhas poedeiras de ovos brancos e marrons, no segundo ciclo de produção: 1. características produtivas. Revista Brasileira de Zootecnia, 28(3), 526-533. doi: 10.1590/S1516-35981999000300013

Baumgartner, S., Brown, D. J., Salevsky, E., Jr., \& Leach, R. M., Jr. (1978). Copper deficiency in the laying hen. The Journal of Nutrition, 108(5), 804-811. doi: 10.1093/jn/108.5.804
Bendezu, H. C. P., Sakomura, N. K., Hauschild, L., Silva, E. P., Dorigam, J. C. P., Malheiros, E. B., \& Fernandes, J. B. K. (2015). Response of laying hens to methionine + cystine intake by dilution technique. Revista Brasileira de Zootecnia, 44(1), 15-21. doi: 10.1590/S1806-92902015000100003

Bertechini, A. G. (2004). Nutrição de Monogátricos. UFLA/FAEPE. $450 \mathrm{p}$.

Brumano, G. (2009). Níveis de lisina e de metionina + cistina e proteína bruta para melhor qualidade de ovo e de carcaça de aves e de suínos. Revista Eletrônica Nutritime, 6(3), 898-917.

Brumano, G., Gomes, P. C., Donzele, J. L., Rostagno, H. S., Rocha, T. C., \& Mello, H. H. C. (2010). Níveis de metionina + cistina digestível para poedeiras leves no período de 42 a 58 semanas de idade. Revista Brasileira de Zootecnia, 39(9), 1984-1992. doi: 10.1590/S1516-35982010000900017

Bunchasak, C., \& Silapasorn, T. (2005). Effects of adding methionine in low-protein diet on production performance, reproductive organs and chemical liver composition of laying hens under tropical conditions. International Journal of Poultry Science, 4(5), 301308. doi: 10.3923/ijps.2005.301.308

Carvalho, L. C. C. (2012). Desempenho produtivo e qualidade de ovos de galinhas poedeiras em segundo ciclo de postura alimentadas com minerais orgânicos. Dissertação de mestrado, Universidade Federal de Uberlândia, Medicina Veterinária, Uberlândia, SP, Brasil.

Carvalho, L. S. S., Vilela, D. R., Fagundes, N. S., Souza, Y. L. S., \& Fernandes, E. A. (2016). Qualidade de ovos e desempenho produtivo de poedeiras em segundo ciclo de postura alimentadas com microminerais quelatados a aminoácidos. Ciência Animal Brasileira, 17(4), 491-500. doi: 10.1590/1089-6891v17i420822

Dalibard, P., Hess, V., Le Tutour, L., Peisker, M., Peris, S., Perojo, A. G., Redshaw, M. (2014). Amino acids in animal nutrition. Fefana, 51. Isbn: 978-29601289-3-2

Dobrzánski, Z., KorczynskI, M., Chojnacka, K., Gorecki, H., Opalinski, S. (2008). Influence of organic forms of cooper, manganese and iron on bioaccumulation of these metals and zinc in laying hens. Journal of. Elementology, 13(3), 309-319.

Empresa Brasileira de Pesquisa Agropecuária. (2019). Desempenho da produção. Recuperado de http:// embrapa.br 
Gambaro, D. V. (2014). Nutrição proteica de poedeiras comercias. Dissertação de mestrado, Faculdade de Medicina Veterinária e Zootecnia, Universidade de São Paulo, Nutrição e Produção Animal, Pirassununga, SP, Brasil.

Idowu, O. M. O., Kuye, O. A., Oladele-Ojo, V. O., \& Eruvbetine, D. (2005, May). The effects of dietary intake and dietary concentration of organic and inorganic copper supplements on egg and plasma cholesterol levels. Proceedings of the European Symposium on the Quality of Eggs and Egg Products, Doorwerth, The Netherlands, 11.

Jenn-Chung, H., Chung-Yi, L., \& Peter Wen-Shyg, C. (1998). Effects of ambient temperature and methionine supplementation of a low protein diet on the performance of laying hens. Animal Feed Science and Technology, 74, 289-299. doi: 10.1016/ S0377-8401(98)001850

Kakhki, R. A. M., Golian, A., \& Zarghi, H. (2016). Effect of digestible methionine + cystine concentration on performance, egg quality and blood metabolites in laying hens. British Poultry Science, 57(3), 403-414. doi: 10.1080/00071668.2016.1173199

Leeson, S., \& Summers, J. D. (2001). Nutrition of the chicken (4nd ed.). Guelph, Ontario: University Books.

Leeson, S., \& Summers, J. D. (2005). Commercial poultry nutrition (3nd ed.). Guelph, Ontario: University Books.

Lien, T. F., Chen, K. L., Wu, C. P., \& Lu, J. J. (2004). Effects of supplemental copper and chromium on the serum and egg traits of laying hens. British Poultry Science, 45(4), 535-539. doi: 10.1080/00071660400001082

Lim, H. S., \& Paik, I. K. (2006). Effects of dietary supplementation of copper chelates in the form of methionine, chitosan and yeast in laying hens. AsianAustralasia Journal of Animal Science, 19(8), 11741178. doi: 10.5713/ajas.2006.1174

Mabe, I., Rapp, C., Bain, M. M., \& Nys, Y. (2003). Supplementation of a corn-soybean meal diet with manganese, copper, and zinc from organic or inorganic sources improves eggshell quality in aged laying hens. Poultry Science, 82, 1903-1913, doi: $10.1093 / \mathrm{ps} / 82.12 .1903$

Maroufyan, E., Kasim, A., Yong Meng, G., Ebrahimi, M., Teck Chwen, L., Mehrbod, P., \& Soleimani Farjam, A. (2013). Effect of dietary combination of methionine and fish oil on cellular immunity and plasma fatty acids in infectious bursal disease challenged chickens. Scientific World Journal, 531397. doi: 10.1155/2013/531397
Mazalli, M. R., Saldanha, T., \& Bragagnolo, N. (2003). Determinação de colesterol em ovos: comparação entre um método enzimático e um método por cromatografia líquida de alta eficiência. Revista Instituto Adolfo Lutz, 62(1), 49-54.

Medici, V., Shibata, N. M., Kharbanda, K. K., LaSalle, J. M., Woods, R., Liu, S., Halsted, C. H. (2013). Wilson disease: changes in methionine metabolism and inflammation affect global DNA methylation in early liver disease. Hepatology, 57(2), 555-565. doi: 10.1002/hep. 26047

National Research Council. (1994). Nutrient requirements of poultry (9nd rev. ed.). Washington: National Academy Press.

Nunes, J. K., Santos, V. L., Rossi, P., Anciuti, M. A., Rutz, F., Maier, J. C., Silva, J. G. C. Qualidade de ovos e resistência óssea de poedeiras alimentadas com minerais orgânicos. Arquivo Brasileira Medicina Veterinária Zootecnia., 65(2), 610-618, 2013. doi: 10.1590/S0102-09352013000200043

Olgun, O., Yazgan, O., \& Cufadar, Y. (2013). Effect of supplementation of different boron and copper levels to layer diets on performance, egg yolk and plasma cholesterol. Journal of Trace Elements in Medicine and Biology, 27, 132-136. doi: 10.1016/j. jtemb.2012.09.005

Patterson, J. A., \& Kung, L. I. (1988). Metabolism of DL-methionine and methionine analogs by rumen microorganisms. Journal of Dairy Science, 71(12), 3292-301. doi: 10.3168/jds. S0022-0302(88)79934-8

Penz, A. M. Jr., Jensen, L S. (1991, december). Influence of protein concentration, amino acid supplementation, and daily time to access to highor low-protein diets on egg weight and components in laying hens. Poultry Science, 70(12), 2460-2466, doi: $10.3382 /$ ps.0702460

Pesti, G. M., \& Bakalli, R. I. (1998). Studies on the effect of feeding cupric sulfate pentahydrate to laying hens on egg cholesterol content. Poultry Science, 77(10), 1540-1545. doi: $10.1093 / \mathrm{ps} / 77.10 .1540$

Polese,C.(2011).Níveisnutricionais demetionina+cistina digestivel para poedeiras semipesadas. Dissertação de mestrado, Universidade Estadual do Oeste do Paraná, Nutrição e Produção Animal, Marechal Cândido Rondon, PR, Brasil.

Richards, J. D., Zhao, J., Harrell, R. J., Atwell, C. A., \& Dibner, J. J. (2010). Trace Mineral Nutrition in Poultry and Swine. Asian-Australasia Journal of Animal Science, 23(11), 1527-1534. doi: 10.5713/ ajas.2010.r.07 
Rezende, J. C. R. (2016), Zinco na nutrição e saúde de frangos de corte. Tese Doutorado, Faculdade de Medicina Veterinária e Zootecnia, Universidade Estadual Paulista, Zootecnia, Botucatu, Brasil.

Rostagno, H. S., Albino, L. F. T., Donzele, J. L., Gomes, P. C., Oliveira, R. F., Lopes, D. C.,... Barreto, S. L. T. (2017). Tabelas brasileiras para aves e suínos; composição de alimentos e exigências nutricionais. Viçosa, MG: UFV. Departamento de Zootecnia.

Rostagno, H. S., Albino, L. F. T., Donzele, J. L., Gomes, P. C., Oliveira, R. F., Lopes, D. C.,... Barreto, S. L. T. (2011). Tabelas brasileiras para aves e suínos: composição de alimentos e exigências nutricionais (2a ed.). Viçosa, MG: UFV. Departamento de Zootecnia.

Sahoo, S. C., Kataria, R., \& Mehta, S. K. (2016). Copper and it complexes: a pharmaceutical perspective. In W. Gruyter (Ed.). Chemical drug desing (pp. 215236). Leck: CPI books Gmbh.

Saldanha, E. S. P. B. (2008). Efeitos de minerais orgânicos no desempenho, qualidade de ovos e qualidade óssea de poedeiras semi-pesadas no segundo ciclo de produção. Tese Doutorado, Faculdade de Medicina Veterinária e Zootecnia, Universidade Estadual Paulista, Zootecnia, Botucatu, Brasil

Scottá, B. A., Vieira, R. A., Gomide, A. P. C., Campos, P. F., Barroca, C. C. \& Formigoni, A. S. (2014). Influência dos minerais quelatados e inorgânicos no metabolismo, desempenho, qualidade da carcaça e da carne de frangos de corte. PUBVET, 8(9), 258, Art. 1710

Sechinato, A. S. (2003). Efeito da suplementação dietética com microminerais orgânicos na produção e qualidade de ovos de galinhas poedeiras. Dissertação de mestrado, Faculdade de Medicina Veterinária e Zootecnia, Nutrição e Produção Animal, Universidade de São Paulo, São Paulo, SP, Brasil
Solarte, W. N., Rostagno, H. S., Soares, P. R., Silva, M. A., \& Velasquez, L. F. U. (2005). Nutritional Requirements in Methionine + Cystine for White-Egg Laying Hens During the First Cycle of Production. International Journal of Poultry Science, 4(12), 965968. doi: 10.3923/ijps.2005.965.968

Souza, J. C. S. M. (2017). Niveis dietéticos de metionina e cobre quelatado, treonina e zinco quelatado sobre a composição química do ovo e o teor de colesterol da gema. Dissertação de mestrado, Faculdade de Medicina Veterinária e Zootecnia, Universidade de São Paulo, Pirassununga, SP, Brasil.

Spence, J. D., Jenkins, D. J., \& Davignon, J. (2010). Dietary cholesterol and egg yolks: not for patients at risk of vascular disease. Canadian Journal Cardiology, 26(9), e336-339. doi: 10.1016/s0828$282 \times(10) 70456-6$

Summers, J. D., Atkinson, J. L., \& Spratt, D. (1991). Supplementation of a low protein diet in an attempt to optimize egg mass output. Canadian Journal Animal Science, 71, 211-220. doi: 10.4141/cjas91023

Sun, Q., Guo, Y., Li, J., Zhang, T., \& Wen, J. (2012). Effects of Methionine Hydroxy Analog Chelated $\mathrm{Cu} / \mathrm{Mn} / \mathrm{Zn}$ on Laying Performance, Egg Quality, Enzyme Activity and Mineral Retention of Laying Hens. Journal Poultry Science, 49, 20-25. doi: 10.2141/jpsa.011055

Valsala, P., Kurup, P. A. (1987, April). Investigations on the mechanism of hypercholesterolemia observed in copper deficiency in rats. Journal of Bioscience, 12(2), 137-142. doi: 10.1007/BF02702965 